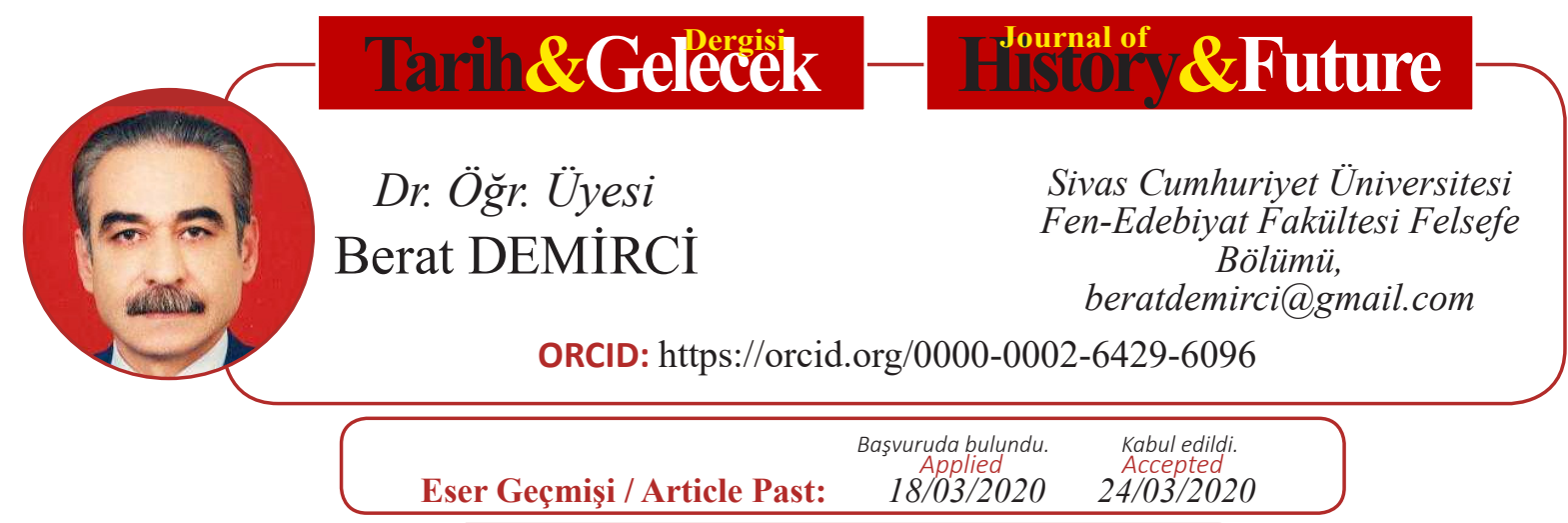

DOI: http://dx.doi.org/10.21551/jhf.705882

Research Paper

Orjinal Makale / Orginal Paper

\title{
Başkaları Ve İktisat Üzerine Etkisi
}

\author{
"Others" and Effect on Economics
}

\begin{abstract}
Öz
Çalışmamızda "başkaları" kavramı, bir toplumun kendi dışındaki toplum ve topluluklara değer

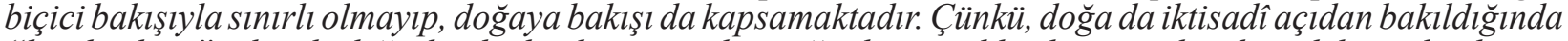
"bir başkası" olarak değerlendirilmekte, rant kaynağl, hammadde deposu olarak sadeleștirilmekte ve ötekileştirilmektedir. Ortadoğu ve Batı çerçevesinde karşılaştırmalara yer verdiğimiz yazımız, -Medeniyetler Çatışması gibi- fundamentalist ve kültüralist görüsslerin temellendirdiği sosyolojistik projelerden farklı olarak, günümüzün ekonomi içerisinde tanımlanan dünyasını tarihî boyutlarıyla anlamayı amaçlamaktadır.
\end{abstract}

Anahtar kelimeler: Başkaları, Ortadoğu, Batı, Rasyonelleştirme, Teknikleştirme.

\begin{abstract}
The concept "Others" used in this study is not limited to an evaluative view of a society cast at societies and communuties outside itself, but includes a view of nature as well. Since nature, from an economical point of view, is evaluated as "the Other", it becomes oversimplified and deliberately converted into "the Other." In this paper some comparisons take place between the Middle Eastern and Western frames of reference-like the Conflict of Civilizations-and the aim here is quite different from the sociologistic projects founded on fundamentalist and culturalist attitudes. The aim here is to understand the world of our day within historical dimensions, instead of defining it within the terms of contemporary economics.
\end{abstract}

Keywords: The other(s), Middle East, West, Rationalization, Technicalization.

ATIF: DEMİCI Berat , "Başkaları Ve İktisat Üzerine Etkisi”, Tarih ve Gelecek Dergisi, 6/1 (Mart 2020), s. $(118-136)$ 


\section{Giriş}

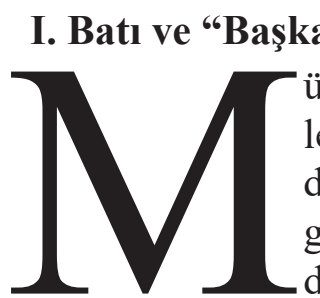

kaları" len kavimlerarası etkileşime ve kültürleşmeye uygun dinî bir gelenek vardır. Eski ve Yeni Ahid bağlıları, kendi dinlerinden sonra yayılan İslâm'1, geleneklerinin bir uzantısı saymaz. Müslümanlık da aynı geleneğin kök değerleriyle ortaya çıkınca Hıristiyanlar ve Yahudiler bunun bir meydan okuma olduğunu hissederek karşı tavır geliştirmişlerdir. Eski Ahid'de kronolojik itinayla dizilmiş vahyî bir geleneği haber verir. Bu haber bir "zaman bilinci”nin kadrana aktarılarak somutlaştırılmasıdır. Yahudi ve Hıristiyanlar, İbrahim'i yalnızca kendi ataları sayarlar; İbrahim'den önceki zaman, adeta "karanlık çağ"dır ve tarih İbrahim'le başlamıştır.

İslam ise insanlığın ve tektanrılı geleneğin tarihini ilk insan ve -aynı zamanda- peygamber de olan Âdem ile başlatır; tarih, bu başlangıç üzerine inşa edilir. Bu yüzden İbrahimî gelenek denildiğinde de Müslümanlarla Hıristiyanların zihnî tasavvurlarında derin farklılıklar vardır. Farklılığa rağmen, Hz. İbrahim üç dinî geleneğin ortak değeri olarak görülür. İslam dini için yalnızca İbrahimî değil, ilk insana kadar ulaşan bir dinî gelenekten söz edilebilir. Bu ise, ilkeldenuygara, basitten mürekkebe, kaotikten mükemmele tarih şemasından izin vermez. İlkel denilen ve genellikle modern uygarlık formlarıyla tasvir edilen toplulukları bir evrim çizgisine yerleştirilemez.

Hz. İsa'nın peygamberliği, Musevîliğin egemen olduğu bir zihnî ve kültürel ortamda gerçekleşmiştir. İsrailoğulları ırkçılığının kabul etmemesine rağmen; Hıristiyanlar, dinlerini Musevîliğin bir devamı kabul ederler. Müslümanlıksa, en insaflı ifadeyle tarih boyunca birbirleriyle pek de barışık yaşamamalarına rağmen birbirini onaylayan bu iki dinin sapkın bir mezhebidir. Günümüzde bu anlayış kısmen ekonomi-politĭgin bir gereği olarak kenarda tutulmaktadır. Fundamentalite ise, siyasî taktik ve manevralarla denetlenebilen bir akışa sahip değildir.

Öteki düşüncesi, İsrailoğulları'nın dünyasında Tevrat'ı millîleştiren Talmud literatürü ile kök salmıştır. Sonraları ise iktisadî bir özelliğe kavuşturulduğu için özgün bir yere sahip olmuştur. $\mathrm{Bu}$ macerada, bir peygambere bağlı Musevîlikten, kavme özel Yahudiliğe geçiş biçiminde seyreden ötekileşme-ötekileştirmeyi gözlemlemekteyiz. Topluluğun tipik belirleyici özelliğinin ticaret haline gelişinin ise bugünün hâkim ekonomik ahlâkı ile bağlantısı tek istikametli değildir. $\mathrm{Bu}$ aynı zamanda kadim bilgilerin hatırlatıldığı Tevrat'tan uygulamaya açık ve projeleştirilmiş bir tarih inşa etmeye imkân veren Talmudî bir geçiştir. Zamana yapılan bu istidracî operasyon, kutsallaştırma yoluyla dünyevileştirilmiş ve tanrısı, tapınağı ve müminiyle akaidsiz bir eylem repertuvarı genişliğine yol açmıştır.

Benzer sosyolojik şartların, aynı sonuçlar verdiğini savunmak anakronizmdir. Sosyolojik şartları farklı olan bir topluluk ard zamanlı olarak dış dinamiklerle benzer yapılara imkân verebilir. Hıristiyanlık cephesinde, Haçlı Seferleri ile başlayan tavır, İsevîlikten Hıristiyanlığa geçiş ${ }^{1}$ biçiminde bir rasyonalizasyondur. İsevilik, batıya mahsus bir din olan Hıristiyanlık haline gelmiş, kuvvetli bir öteki anlayışına sahip bu dünyevileşme hareketi, feodal birimlerin merkezkaç mayalanmalarının da bir bütünleştirme ideolojisi olarak ulusçuluğun tırmanışına da zemin oluşturur. Batı dışındaki milletlerin tamamının ve tabiatın öteki olarak değerlendirilişi merkantilizmden kapitalizme geçişi kolaylaştırmış, günümüz teknik uygarlığının da hazırlayıcısı olmuştur.

1 . "Hristiyan” kelimesi Grekçedir. Greklerin vermiş olduğu isim, İsevîler tarafından kabul edilmiştir. 
Haçlı seferleri farklı etnisiteye sahip unsurları, başkaları olarak nitelendirlen, Müslümanlara ve diğer topluluklara karşı her alanda birleşmenin dinî temelidir. Bu temel kilise ile dünyevî güçlerin ittifakından doğan bir uygarlık zemini oluşturmuştur. Ötekileştirme, ezici ve operasyonel bir teknik olarak modern uygarlığın kaosu düzene çevirmede en kuvvetli manivelasıdır.

\section{A. Yaradılışın Mistik Hikâyesi}

İncil ravîleri, Hz. İsa'yı yeni Musa ve Eski Ahid'i tahakkuk ettiren şahsiyet olarak takdime gayret ve titizlik gösterir. ${ }^{2} \mathrm{Bu}$, Eski Ahid'in tasdikidir. Çoğu kez birbirine hasım yaşayan iki dünya gücünün dinî metinlerinin, hasımlardan biri (Hıristiyanlık) tarafından dinin tamamlayıcısı ve devamı olarak kabulü, insanlığın süregelen tarihi açısından bugünlerin ekonomi-politiğini belirleyen en mühim hadisedir. Çünkü Musa'nın tebliği ve iç içe geçmiş Yakındoğu kavimlerinin esatirinden süzülmüş Tekvin bölümü hariç̧3, Kitab-1 Mukaddes'in bütün bölümleri ya Yahudilikte olduğu gibi bir kavim yahut Hristiyanlık'ta olduğu gibi bir din mensuplarının tarihidir. Tekvin ise insanlığın tarih öncesinin bir izahıdır; ötekileştirmenin arketipleri orada gizlidir. Tekvin, mitolojik örgüsüyle tarihîleştirmeye imkânı vermez ama ötekilerden ayrışan bir zihniyet teşekkülü olarak Yahudiliği anlaşııı kılabilir. "Ben"in bir kuvvet olarak kendini imtiyazlı varlık olarak ötekileştirmesi, kendi dışındakileri ise öteki olarak karşısına alması; Talmud'un aç̧tğı imkândır.

Tekvin, zihnî ve imanî evrim suretiyle tekleşen tanrı inancının ve tarihî evrim geçirerek dinîleşen bir toplumun hikâyesidir'. Hikâyede: Sümerlerden Akadlara, Babilden İsrailoğulları'na bütün Sami dünyasının esatiri vardır. Dinî esatirde tek tanrılılıkla, çok tanrılılık arasında gidip gelen bir kargaşa söz konusudur. Tekvin'in dercedilmesi, nasıl kaostan yaradılışa İsrailoğullarının tarih öncesini boşluk bırakmaksızın aydınlatmaya çalışan bir çaba ise; Eski Ehid'in diğer bölümleri de zamanın her anında kendini hissettiren kaos'un giderilmesinin İsrailî bir yoludur. Çaba ve yol: Primat (adam), toplum ve tarih oluşturmakla kalmayıp, başkalarını -tabiat ve insanı- kendi lehine alabildiğine basitleştirerek Sınırsız Karışıklığın üstesinden gelmeyi alışkanlık haline getirmiştir.

\section{B. Herkesin Tanrısı'ndan İsrail'in Tanrısına}

Tevratın derlenişi asırlar sürmüştür ve yazılı metinler birçok kavmin sözlü kültürünün izini taşır5. Derleniş öncesi şifahi kültürün oluşumunda, din adamları, şairler, halkın günlük yaşayışını aksettiren anonim ürünler çift yönlü bir akışla gündelik hayata sirayet etmiş: bir yandan masallar, türküler, destanlar dinîleştirilirken; bir yandan da dinî esatir masallaştırılmış̧ır. Masal sathında gezinen ravîler, Eski Ahid bölümlerini yazıya geçirmeden önce, üzerinde kalem oynatmaya mü-

2 . Thomas Michel, Hristiyan Tanrıbilimine Giriş, İstanbul: Ohan Basımevi, 1991, s.34-35.

3 . Hz. Âdem ve Nuh, İbrani geleneğinin başlangıcı olarak değil, İbrani tarihinin karanlık devirlerini açıklamak için vardırlar ve onların kıssaları Musa’nın kelamından değil, şifahi dinî gelenekten aksettirilir.

4 . Tekvin'de yorulan, yemek yiyen (Tekvin: 18), insanla güreş tutan bir tanrı(Tekvin: 32) varken; Çıkış’tan itibaren beşeri zaaflardan arındırılır. Tekvinin tamamı iki ayrı yazıcılar grubunun elinden çıkmıştır. Tevrat uzmanlarının Yahveciler ve Elahimciler olarak tesbit ettiği bu gruplarda, tanrı inancı büyük farklılıklar taşır. ahve(Yahova), eski bir İsrail tanrısıdır ve Yahveciler'in kaleme aldığı bölümlerde, beşeri zaaflarıyla sezilmektedir; Elahim ise, Bütün Samî milletlerce El, ilah, Allah lafızlarıyla maruf tek tanrıdır ve tevhidî geleneğin habercisidir. Yahve insanlarla şaşırtıcı derecede yüzgöz olan yakındoğu cemaat ya da tabiat tanrılarına benzerken; Elahim, insanlara ya bir melek vasıtasıyla, ya da değişik bir sesle vahyeden, maveraî ve tek bir tanrıdır.(Geniş bilgi: Hayrullah Örs, Musa ve Yahudilik, Istanbul: Remzi Kitabevi, 1966.)

5 . Torah(= Musa’nın Beş Kitabı) Hristiyanlar için de kutsal sayılır ve muhtemelen MÖ V. yüzyılda son şeklini almıştır. Bu karmaşık teşekkül safhasında yığınlarca insanın emeği varsa da bir çoğunun adı unutulmuştur. Yahudiler ve Hristiyanlar, emek veren ruhanîlerin için Tanrının ilham verici gücü tarafından yönetildiğine inanırlar. (Thomas Michel, Hristiyan Tanrıbilimine Giriş, s. 22.) 
sait konular ve özellikle karanlık devirler bulmada güçlük çekmez ${ }^{6}$. Karanlık devirler, şifahi Ortadoğu kültürünün zengin esatirî malzemesiyle bezenerek aydınlatılır ve evrimi tarifeye bağlayan bir İbranî tarihi inşa edilir. İnşa edilen tarih, yazıya geçirilirken, bütün ihtimama rağmen farklı kültür ve tercihlerin etkisiyle zaman zaman birbirini çelmeleyen unsurları da barındırarak, geleceğe elvermiştir.

Başlangıçta Musevîler, Misır ve Sümer (Babil) medeniyetlerine ve çoktanrılı dinlerine karşı kendilerini korumuşlar; koruma esnasında da muhtemelen önceki dinlerin esatirinden geçen ${ }^{7}$; ama birçok kadim kültür gibi kozmik birliğe dayalı bir evren tasavvuruna da sahip Misır ve Babil inancına daima hücum halinde olmuşlardır. Tabiat ile tabiatüstünü, deneylenebilirle deneyüstünü birbirinden ayırmayan Misır ve Babil medeniyeti, birleyici kozmoloji tasavvuruyla Musevîliğe ve diğer yakın doğu geleneklerine benzer ${ }^{8}$. Bu kozmolojik anlayışı sarsan, İsrailoğullarının olanca gayretleriyle esatirî sözlü kültürlerden kendilerine mahsus bir kutsal metin, bir din süzme çabasıdır. Süzme çabası, -Tanrı tasavvurunun bulanıklığından doğan- çokluktan birliğe doğru sürerken, yalnızca İsrailoğullarına özgü bir tevhidîlik çıkarır. Tevhid, Mısır ve Babil tanrılarının halk içindeki esatirî etkilerinin, ruhbanlar vasıtasıyla ve rasyonel (akıl yürütücü) tercihlerle kırılarak ulaşılan bir tevhiddir. Yahve ya da Elahim9, Hz. Musa'ya vâhyedilenle eski kültürlerin kozmik tasavvurlarının harmanlandığı bir coğrafyada, önce aşkınlaştırılmış, sonra tarihîleştirilmiştir ${ }^{10}$. Aşkınlaştırma, Mısır ve Babil karşısında sinmiş sindirilmiş İsrailoğullarının içten içe sürdürdükleri husumetle aşırılığa sürüklenmiş; Yahve, çeşitli tanrı tasvir ve tasavvurlarından tenzih edilirken, tabiattan da uzaklaştırılmıştır. Giderek Eski Ahid, kendi yarattı̆̆ı, fakat karşısına alıp içine nüfuz edemediği evrenin $d \iota s ̧ ı n d a$ duran bir tanr ${ }^{11}$ inancında karar kılmıştır.

Tabiatla tabiatüstünü birbirine bağdaştıran kozmolojik evren tasavvurunun hesapların dışında tutulması hareket serbestliği getirmiştir; geleceğin ne getireceği bilinebilir bir şey değildir ve bu bir tedirginlik kaynağıdır. Tanrı ile zaman arasındaki bağın değerlendirilişinde de tabiata

6 . Maurice Bucaille, Tevrat İnciller ve Kuran, Çev. Dr. M.Ali Sönmez, Ankara: DİB Yayınları, 1982, s.27.

7 . Hz. Musa'nın sözlerini tasdik eden Firavun'un bilgin(büyücü)lerinin, bu sözlere benzer bir şifahi kaynaktan haberdar olmamaları düşünülemez; çünkü, iman ederken inatçılık sergilememiş̧lerdir (Kur’an, A’râf: 120-122). Fakat, Eski Ahit, Hz. Musa'nın Firavunun sarayına tebliğ için değil de, yalnızca İsrailoğullarının esaretten kurtarılması için gitmiş olduğunu anlatılır (Çıkış:10-11). Tanrı, yalnızca İsrailoğullarının Rabb’ı olmak “ahd”inde bulunmuştur; başka kavim ve kültürler Musa’nın çağrısına kapalıdırlar.

8. Mısırlıların resmî dinleri çoktanrılı olmasına rağmen, masal ve şiirlerinde kozmolojik bir geleneğin varlığı, tevhit inancından sapma gibi gözükür. Ayrıca, Eski Mısır şiirleri ile İbrani şiiri arasında büyük benzerlikler ortaya çıkmıştır (Meydan Larousse, Eski Mısır maddesi).

Bu benzeyişin temeli, sürekli peygamberlerle ve aynı gelenekle yüz yüze olan bir coğrafyanın inanç halitasıdır. Çok tanrılılık içerisinde bile, bütün tanrılara baş eğdiren bir ulu tanrının varlığı söz konusudur ve bu topluluklar içerisinde yalnızca eski peygamberlerin getirdiğiyle iman eden insanlar da vardır ve bütün bunlar beraber yaşamaktadırlar.

9 . İki ayrı Tekvin rivayetinde Yahova ve Elahim ismiyle tanıının iki ayrı isimlendirilişinin varlığı onun iki ayrı metnin sentezi olduğunu göstermesine rağmen, sonraki dönemlerde iki ayrı metin yokmuş gibi, yalnızca Yahova adı vardır; Elahim, Sami dünyasının müstereken kulländı̆̆ı Allah lafzı olduğu için terkedilmiştir. Yahova’nın eski bir Israil tanrısı olması sebebiyle millî bir kabul görmuştür.

10 . Peter L. Berger, Dinin Sosyal Gerçekliği, Çev. Ali Coşkun, İstanbul: İnsan Yayınları,1993, s.172.

11 . Peter L. Berger, s. 172. (Metin içindeki italik yazara ait...). Musevilerin Allah’a besledikleri saygı öyle bir hâle bürünür ki, adını tenzihte kusur etmemek için çoğu kez söylemekten bile çekinirler ve Rab, Gök gibi kelimeler kullanmışlardır; aynı tavır hristiyanlarda da vardır. Mekandan, zamandan, yönden, gökten, yerden münezzeh Tanrı, yalnızca İsrailoğullarına yakındır. Bu yakınlık, İsrailoğullarının kendilerinin gelmiş geçmiş en seçkin millet olduğu inancına vardırır; 1rkçılığın kutsallaştırılması onları, Allahla İsrailoğulları arasında daimî bir ahid vardır imanına vardırır. Tanrının böylesine aşkınlaştırılması, İsrailoğulları tarihinin hangi safhasında oluştuğu kestirilemez ama bu süreç sekülerleşmenin kapılarını açar. Tabiat ve zaman ahid gereği topyekûn İsrailoğullarının tasarrufuna sunulmuştur; Tevrat ravîleri, örneğini Yeni Ahid'in kayda geçirilmesinde gördüğümüz Tanrı ilhamına açık azizler olarak teoloji geleneği oluştururlar. 
bakıştaki farklılaşmaya benzer bir dönüşüm yaşanır. Tanrı, çoğunlukla zamanın dışında duran ve ancak İsrailoğullarıyla ahdini hatırladığında eşya ve tarihî vakıalarda onlar lehine tecelli eden bir tarihî olgu olarak tabiattan tefrik edilir. Bu doğanın "başkaları” kategorisine sokuluşudur. Tanrı, ezelî ve tek tanrıdır ama, aynı zamanda yalnızca İsrail'in başlangıcıyla milatlaştırılan ve doğada kendini öyle gösteren bir tanrıdır. Ezelî olduğuna inanılanın milatlaştırılması aşırı basitleştirici ama etkili bir topluluk dininin temellerini oluşturur; öyle ki, tanrı artık İsrailoğullarıyla beraber hareket eden seyyar bir güçtür ${ }^{12}$. Zamanın, belirli bir kavmin yeryüzündeki serüvenine indirgenmesi ve tarihi olayların doğru bir hat üzerinde gerçekleştiği kabulü; dünya görüşünü biçimlendiren imanî bir tavır olmakla kalmayıp, tarih yazıcılığını da yönlendirmiştir. Bu seçmece (eklektik) usül: Evren tasavvurunda kozmik değil, mekanik; insan ve topluluklar hakkında milatlaştırıcı, evrimci ve salt determinist yaklaşımın temelini oluşturur.

\section{Zealodyen Ticarî Ahlak}

Yahudilerin tarihi üzerinde Kitab-1 Mukaddes'de de ayrıntılı bir biçimde anlatıldığı gibi Helenizmin kültürel baskısı ile Roma işgalinin sindirici rolü olmuş, karşıkoyanlar (Herodyenler) şiddetle cezalandırılmışlar ve yahudiler bir daha kendilerini toparlayamamışlardır. Ancak, Tevrat ve genel hatlarıyla israioğulları'nın akaidi arkaikleşmemiş, -Zealodyen tavır geliştirerek- yeraltına çekilmiştir ${ }^{13}$. Kendi içinde zaten kavmiyetçiliğe müptela İsrailoğullarının tavrı, Roma ve Helen istilasının Yahudilere karşı kıyıcılığı ve emperyalist tavrı ile birleşince, Musevîlik inanç olarak yayılma şansını yitirmiştir; ancak, yaygın bir zihniyet olarak etkin konumunu korumuştur.

Babil ve Mısır medeniyeti ikliminde, tevhid ile çoktanrılılı̆̆ın hem iç içe, hem kavgalı yaşadığı bir muhitte, daima bir direniş ahlakıyla kendini koruya gelen İsrail inancı, Helen ve Roma dönemine erdiğinde bir dünya görüşü ve zihniyet inşasının yazıyla kayıtl11 ${ }^{14}$ ve tecrübî bir timsali olarak tarihteki yerini almıştır. İsrailoğullarının arz üzerinde bulunduğu şartlara göre tavrını ayarlayan dinî bir kimlik ve tabiat karşısında geliştirdiği vatansızlık pragmatizmi, kendinden sonra kıtalar arası bir uygarlık haline gelen Batı dünya görüşünü de için için etkilemiştir.

Roma'nın iki Yahudi kıyamını kanla boğmasından ${ }^{15}$ sonra, bir daha topluluk olarak yaşayamamışlardır; ancak, bu tarihten sonra her yahudi ferdi, bir Zealot'ttur. Zealot ahlakın direnişine rağmen Yahudilik, Roma'nın askerî ve siyasi gücü, Helenlerin kültür emperyalizmi karşısında boyun eğmiş ${ }^{16}$, yaşadığımız asra kadar da toplum ve devlet olarak yaşama şansını yitirmiştir. İhtilalci ve savaşçı Zealodiyen ahlakının, her hâl ve şart içinde Yahudi kalmak ve daima

12. Yahova’nın Sina'daki mİsaktan ve göçebeler federasyonunca Savaş Tanrısı olarak kabul edilmezden önce de volkan ya da firtına tanrısı olarak varolması, İsrailoğullarının akidelerinin teşekkülünde önemli gibi gözükmektedir. Yahudi tanrı anlayışının, tabiat ve cemaat tanrılarının Mısır inancında yerine getirdiği göreve benzer bir şekilde kendini göstermesi ilginçtir. (Toynbee, Tarihçi Açısından Din, çev. İbrahim Canan, Istanbul: Kayıhan Yayınevi, 1978)

13. Toynbee, Medeniyet Yargılanıyor, çev. Ufuk Uyan, İstanbul: Yeryüzü Yayınları, 1980, s. 180-181.

14. Tevratın şifahilikten çıkarak kayıtlı hale gelmesi bir tarafa, İsraioloğullarına ait en küçük bir ayrıntının bile muhafaza edildiği Talmud metinleri, yahudileri daima diri tutmuş; sayıları hiçbir zaman fazla olmasa da dünyanın neresinde olursa olsun, Zealot tavır içinde olmuşlardır.

15. İsrail'in son devleti Herodes devridir. Herodes, adı ile anılan herodien tatbikatıyla İsraili yaşatmış ama; halk, büyük oranda helenleşmiş, yahudiliğinden utanır olmuştur. MÖ IV yüzyılda Herodes'in ölümü, yaşamak pahasına boyun eğen Yahudileri başsız bırakmıştır (Roma Ansiklopedisi, Atlas of the Roman World'un Türkçe çevirisi, İstanbul: İletişim Yayınları, s.162-163). Yukarı tabaka, tamamen helenleşmiş romalılar gibidir; fakat Zealotlar(Yahudi direnişçiler) isyan ederler. Bu isyan pek zalimane bastırılmıştır. Herodienlerin çoğu Helen, Roma kültürü içerisinde erirken; Zealotlar, artık devletsiz ama, dünyaya karşı yeni bir tavırla yahudiliği yaşatmışlardır.

16. Rene Sedillot, Değiştokuştan Süpermarkete, İstanbul: 1982, s.50. 
başkalarından üstün olduğu bilincini ayakta tutmak biçimine dönüşümü; hakiki etkisini ticarî hayatta göstermiştir.

Yahudiler; iktisaden gelişmiş, kurumlaşmış ve serbest ticarete yatkın Babil ve devletçi olmasına, gelişmiş bir ticaret bürokrasisine sahip Mısır medeniyetini yakından tanımalarına rağmen; inançlarının etkisiyle de Mısır'da hüküm süren bir nevi köleci kapitalizme ve Babil'in tüccar tabiatına cephe almışlardı. Fakat israil'in parlak ve devletli yılları onları iktisadî hayata yakınlaştırmış; ticarî hayata yatkınlıklarını keşfetmişler ve ticarette yahudi tipi belirginleşmişti ${ }^{17}$. Roma'nın yaptığı kıyım sonrasında ise ticaret, yahudilerin kaderi ve tek meslekleri olmuştur ${ }^{18}$.

Yeni Zealotlar, kitaplarının oluşmasından, geleneklerinin biçimlenmesine kadar geçen çağlar boyunca kendilerini ilahî ilhama açık bir kavim olarak gördükleri için geniş bir eylem serbestliğine sahiptirler. Bütün yeryüzü onların ticarethanesidir ama herşey, kutsal Yahudiliğin yaşaması içindir... Yahudiliğin topyekûn, Protestanlığın batı üzerinde asırlar sonra yapmış olduğu dönüşüme benzer bir dönüşüm geçirmesi ve bu dönüşümün odağının ticaret olmasi ${ }^{19}$, iktisadî zihniyetin teşekkülü açısından küçümsenecek gibi değildir. Kapitalizmin bütün tarihini Yahudilikle izah etmek güçtür. Fakat kapitalizmin bir sistem olarak, İsraioğulları'nın hayatta kalmak için başkaları ile kurduğu her türlü ilişkiyi ticarete indirgeyerek iktisadî ahlakı, teknik haline dönüştürmesi söz konusu edilebilir.

\section{HELENiSTIK ROMA VE HIRISTIYYNLIK ARASINDA BATI}

\section{A. Kutsal Metin, Prometheus ve Adem}

Kutsal Kitap, Helenizmle tanışmadan evvel devşirilmiş ve kayda alınmıştır; eski Yunan'ın esatirî kahramanı Prometheus'un Kitab-1 Mukaddes'te yerinin olması neyle izah edilebilir? Kavimler, kendileri için tarih yazarlar ama varlıklarını tarihle izah etmezler; hepsinin yaygın bir zihniyet alanı olarak kutsallaştırılmış bir türeyiş destanı vardır. Efsanelerin doğuşuna tarih düşülemese de doğdukları yer önemlidir. Rab, yasak meyveyi yiyerek iyiyi kötüyü bilmekte tanrının gücüne ulaşınca, "elini uzatmasın, hayat ağacından almasın ve yemesin ve ebediyyen yaşamasın diye... Aden bahçesinden yeryüzüne kovdu...’(Tekvin, Bab:3). Metnin kendi bağlamı içerisinde yığınlarca çelişki iç içe gibi gözüküyor; Âdem yasak ağaçtan yiyince ilahlaşıyor, ilahlaşınca husumete uğruyor; Rabbin Âdeme celallenmesinin sebebini bildiren "bizden biri oldu..."20 ifadesi, çoğul anlaşılırsa ilâhlar, tekil anlaşılsa da, bir ağaçtan meyve yiyerek beslenen (ya da bilgi edinen) bir Zeus gibi gözüküyor.

Tufan'ın yüzyıllar sonra Sumer destanı haline gelmesi, Nuh'un tek tanrılı dininin, çoktanrılılığa dönüşmesi gibi gözüküyor. Sumerlerde de insan (Gılgamış)", "Tanrıların

17. "Yahudi bu hayat sahasına hayli geç ve hayli duraksayarak girdi, ama sonunda hiç kimse onunla artık boy ölçüşemedi.". (Sedillot, s.50).

18. Zealotların din için canlarından geçecek kadar kuvvetli imanlarının; canlarını korumak için ticarî ahlak geliştirmeleri, Avrupa tarihinde protestanlık kadar sathî genişliğe sahip olmasa da, derinliğine etkileriyle küçümsenecek gibi değildir.

19. Marx’ın ilk makalelerinden birinde Yahudi meselesini anlatırken şu ifadeleri ilginçtir: Yahudilik, bir grup veya kastın dini; kendini ticarete vermiş, dağılmış bir kavmin enkazıdır. Bu itibarla antisemitizm sadece "ideolojik" bir şey değildir, onun da ekonomik ve sosyal bir temeli vardır; bu, bir rekabet olayıdır. (Henri Lefebvre, Karl Marx (Hayatı ve Eserleri), çev: M. Reşat Baraner, I. Bask1, Ankara: Anadolu Yayınları,1968, s. 111-112.)

20 .Aynı konu Kur’anda tamamen zıttır. İblis, Ademe ve eşine Allahın yasakladığı ağacın meyvesinden yerlerse tanrılaşacaklarını, yasağın bu yüzden konulduğunu fisıldar. Kur'an'a göre şeytanın söylediği sözler, Tevrat’ta Yahve'ye aittir. Grek mitolojisine uyar.

21. Gılgamış da Prometheus gibi, insanları kötülüklere karşı koruyan, her șeyi öğrenmiş, zekanın gizli sırlarını keşfetmiş, yarı tanrı yarı insan bir kahraman. (Şemseddin Günaltay, Türk Tarihinin Ilk Devirlerinden Yakın 
bahçesi”nden meyve çalıyor; Gılgamış'ın büyük atası, Upanidşim (Tufan'ın Sumer uyarlamasının Nuh peygamberi), en büyük ilâhın bahşıyle tanrılaşarak ölümsüzlüğe kavuşuyor ${ }^{22}$... Sümerlerin dini ise, büyük tapınakta ikamet eden baba tanrısıyla, kadınlı erkekli mevcudiyetleriyle, kapris ve rekabetleriyle kadim Yunanın aynısı. Tercüme değil, kültür iktibası; ama mutlaka öncelik ve sonralık söz konusu; Yunan daha sonra, yani iktibası yapan onlar... Tarihî açıdan bilgi ve teknoloji iktibaslarını komşu kavimlerin etkileşimi ile izah etmek kolaydır; ancak, medeniyetlerin sayıklamalarının ve rüyalarının iktibası, etkileşim değil köken bildirir²3. Eğer çok katı bir kültür evrimi şemasına uyup, şema içerisinde bütün topluluklara bir konum belirlemeye çalışılmazsa; Prometheus'un bir yönüyle Âdem'e benzeyen ama birbirinden farklı sonuçlara vardıran hikâyelerinin, Sumerlerde efsaneleştirildiği ve birbirlerine çok benzer ana temalarıyla Grek’e geçtiği söylenebilir.

Tarihî hakikatlerin imanın macerası boyunca, akideye -dinin Tanrı’ya bakışına- transfer edilişi, inancı tamamen tarihin akışınca biçimlendirilişine elverir... Akaid zaman üstüdür ve değişmez. "Yeni ve eski Ahit' in kıssalı bölümlerinde tarihsel, efsanevî ve mitolojik unsurlar bir araya getirilmiştir ve birçok olayda bu unsurları herhangi bir şekilde birbirinden ayırmak imkânsızdır."24 Kıssalar için Tillich'in söylediği bu sözler, Kitab- Mukaddes’in diğer bölümlerinin de tarihi olaylardan ve mitolojiden etkilenmemiş olamayacağını göstermez. İmanın -akaidî esaslarıntarihten etkilenişinin, inançların etkilenişinden farklı sonuçlar doğurduğunu düşünüyoruz. Çünkü inançların tarihî akış içinde uğradığı kırılmalar, akaidî esaslarla daima bağıntılıdır. Daha önemlisi, kıssaların -mitolojik unsurların- kutsal kitaplardaki farklılıklarının, toplumların/toplulukların kozmolojik ve ontolojik bakışlarının, insan ve tabiat hakkındaki geliştirdikleri tavırların aranacağı yer olmasidir.

\section{B. Ortadoğu ve Helenistik Roma}

Eski Yunan, Ortadoğu'nun Akdeniz ve Anadolu köprüsüyle batıya açılan kapısı ve son sınırıdır; sonra Ortadoğu, helenizmin maharetiyle Romaya akar ${ }^{25}$. Roma'nın cemaat tanrıları, helenizmin etkisiyle Yunanîleşir; isimleri Latince, yaptıkları işler ve macera ise Grekçedir. Roma köylülerinin (paganlarının) helen etkisine girmesi, inanç alanında başlamıştır. Öte yandan, Ortadoğunun önemli bir uygarlık hinterlandı olan Mısır'ın devlet bürokrasisi ve teşkilatçılığı Romayı derinden etkilemiştir. Roma'nın Mısır medeniyetiyle temasından sonraki ekonomik tarihi, Ortadoğu kaynaklı müesseseleri imparatorluğun temel unsurları haline getirmek olmuştur ${ }^{26}$. Grekler; kültürleriyle olduğu kadar, Akdeniz ve Anadolu'nun ticarî ahlak ve alışkanlığını taşıyor olmakla, denizcilikleriyle kendi coğrafyasının imkanlarını zorlamış bir ekonomi geleneğine sahiptirler ve Romaya tesir etmişlerdir.

Antik Yunan fesefesi ile Roma arasında önemli bir kültür geçgisi de israiliyatın batıya

şark- Elâm ve Mezopotamya- Ankara: TTK Yayınları, 1987, s.220-221). Gılgamış bir yüzüyle Prometheus, bir yüzüyle onu tanrıların tasallutundan koruyan ve kurtaran Herakles...

22. Destanlar hemen hemen tam metin Günaltay tarafınan yayınlanmıştır.

23. Akdeniz, Tuna nehri, Atlantik ve Baltık denizi yüksek doğu kültürlerinin Avrupaya giriş kapıları olmuş ve bu kültürler sonraları Yunanistan'da bugünki Avrupa’ya temel olan klasik medeniyeti oluşturmuştur. Bu medeniyetin çiçeklenme dönemi doğuda, İskenderiye'de gerçekleşmiştir ve bütün tarihi boyunca Avrupa'dan ve kara Yunanistanın'dan uzaktır. (Chrıstopher Dawson, Batının Oluşumu, çev. Dinç Tayanç, İstanbul: Dergah Yayınlar1, 1976, s. 25-26.)

24. Paul Tillich, İmanın Dinamikleri, Ankara: Ankara Okulu Yayınları, 2000, s.80.

25. Dawson, s.40.

26. Dawson, s.39-40. 
doğru akışıdır. Efsaneye göre yetmiş iki, yahudi alim Tevrat'1 harfiyyen Grekçeye çevirirler ${ }^{27}$. İsadan yaklaşık üç yüz yıl önce gerçekleşen bu hareket, yahudiliği yaygın bir kültürün diliyle geniş bir coğrafyaya taşımıştır. Peygamberle, azizleri benzeştiren bir teoloji anlayışının, bilginin temsilcilerine o gün açmış olduğu zihnî çığır, batının geleceğine uzanır; Hıristiyanlar da Yeni Ahid ravîlerinin ilahî ilhamla hareket ettiğine ve peygamberane bir görev yerine getirdiklerine inanmışlardır. İlahî ilhama tabi olmak, bilginin teşekkülünde Kilise'yi önemli bir mevkiye getirmiş; Kilise'nin kurumlaşmış haliyle cedelleşmeye kalkışan her bilgi arayışı, teolojik bir temellendirme merhalesini yaşamak zorunda kalmıştır. Bu teolojik temellendirme çabaları, kaos ve çıkışlar biçiminde bir tarih anlayışı da oluşturmuştur.

\section{Koas ve "Çıkış"ların Tekniğe Bağlanması}

Helenistik Roma'nın Ortadoğu ve Akdeniz'den Avrupaya akarken taşıdığı ruh, Hıristiyanlık değil Babil ve Mısır'ın ruhudur. Babil'in, Kaos'un içinden çıkan tanrıları ${ }^{28}$, dünyaya nizam verdiğinde Eski Yunan yoktur. Eski Yunan'ın Yaradılış Destanı da Babil'in aynı: ilkin bütün tahripkârlığıyla Kaos vardır ${ }^{29}$... Yeryüzü gökyüzüyle yatar Cronos, annesiyle yatar Zeus dünyaya gelir, Zeus'un ilk işi babasını bertaraf etmektir ve oradan başlayarak Kaosu yok etmeye çalışır, hiçbir zaman yok edemez, tedrici düzenlemelerle Kaos'u dizginler... Hikâyeler birbirinin aynı ama Günaltay’ın ifadesiyle: "Sumer heyeti içtimaiyesi, ahlaki salabet ve fazilet itibarile..."30, Eski Yunan'dan ileridir. Babil yaradılış destanının -Hz.İbrahimin dininden geçip geçmediğini bilmiyoruz- yazıcılara yapmış olduğu etki sonucu olsa gerek böyle bir kaos halinin Tevrat'ta da yeri vardır: Rabbin oğulları vardır ve bu oğullar insanların kızlarının güzel olanlarını seçerler... Bu kızlar Tanrının oğullarından çocuklar peydahladıklarında, yeryüzünde zorbalık vardır. Nuh, Kaostan kurtuluşun yolu olur ${ }^{31}$. Eski Ahid, Hz.Musa'dan başlayarak, ard arda kaos ve kaostan çıkışın maceralarıyla doludur.

Aziz Augustin, "Çıkış”ı formüle ederek, batı dünyası için önemli bir tarih anlayışını başlatır. Daha öncesinde Grek ve Roma’da varolan Tanrı Devleti kavramını, zamanın sonuna kadar geçen tüm anlara yaymakla: Logos’u evrenin düzenini, kozmosu yöneten öncesiz ve sonrasız akıl olarak düşünen, ama sadece insanları ilgilendiren bir geçmiş ve geleceğe bağımlı kılmayan Antikçağ' dan ciddi bir ayrılışı gerçekleştirmiştir. ${ }^{32}$ Tanrı Devleti, gerçek hükmünü kıyamet günü sürecek olan

27 . Ptolemeler zamanında Tevrat, hâkim kültür olan Grekçeye çevrilir. Kral II. Ptolomeaus, dünyanın her tarafından kitapları tercüme ettirerek büyük bir kütüphane kurar, ama içlerinde Tevrat yoktur. Kendisine bunun büyük bir eksiklik olduğu söylenince, baş kahinden yahudi alimler isteyerek Tevratı Grekçeye çevirttirir. Efsaneye göre, çeviriyi yapan yetmiş iki alim, yetmiş iki ayrı odada çalışırlar ve herbirinin İbraniceden Grekçeye çevirdiğ Tevrat birbirinin aynıdır. Bu çeviri Grekçe vasıtasıyla yahudiliğin yakınen bilinen bir din haline gelmesini sağlamış ve daha sonraları hristiyanlarca da muteber görülmüştür.

28. Babil yaradılış destanı(Enuma Elis), Kaos’tan çıkışın hikayesidir. İlk varlık baba Apsu, varlıkların hepsinin anası Mummu Tiamat ile sularını birbirine katarlar. Sonra, diğer ilahlar zuhur ederler. İlahların uzun mücadelelerinden sonra, Tiamat, büyük oğlunu kutsar ve ona "kaderler levhasını" verir (Şemseddin Günaltay, s. 407-413). Bu destan Asurîlerde de, Akkadlarda da ağızdan ağıza aktarılmıştır. Mısır için, bu inançlar yabancı olmadığı muhakkak, ancak din onlarda iktidarı güçlendiren merkeziyetçiliği berkiten bir unsurdur. Helenistik dönem sonrasında Mısır medeniyeti son demini, merkeziyetçi devlet anlayışı ve bürokrasisi ile ise en olgun zamanını yaşamaktadır... Pitolomelerin devlet teşkilatı Roma’ya teşkilatçılık aşılar.

29. "Mezopotamyalılarda da Yunanlılarınkaoskavramınabenzerbirfikrinolduğugörülmektedir. Mezopotamyalılarda, bu kaostan ilkin tanrıların çıktığı, bunlar arasıında yaratıcı bir tanrının belirdiği, ve bu tanrının yeri, yıldızları, ve insanı yaratmış olduğu kabul ediliyordu." (Aydın Sayılı, Mısırlılarda Ve Mezopotamyalılarda Matematik, Astronomi Ve Tip, Ankara: TTK Basımevi, 1982, s.338.

30. Günaltay, s.459.

31 . Eski Ahid, Tekvin:6. Bab,1-8.

32. Bu konuda: Doğan Özlem, Tarih Felsefesi, İstanbul: İnkılâp Yayınları, 2001) ve (Macit Gökberk, Felsefe Tarihi, 
teokratik devlettir; Yeryüzü Devleti Tanrı ile en bağlantısız halinde bile teolojik bir devlettir. Bu hem ciddi bir rasyonelleştirme hem kaostan çıkışın teknik bir yoludur.

Kaostan çıkışın teknik yolunu modern zamanlara bağdaştıran temel, Augustin'in tarihi şemalaştırmaya elverebilen ve çağdaşımız sayılan pekçok Batılı tarih felsefecisine ilham kaynağ olmaya uygun zaman anlayışıdır: "Ne gelecek var ne geçmiş ne de 'geçmiş, şimdiki, gelecek zaman diye üç zaman var' demek yerinde. Belki şöyle demek yerinde olur: 'Üç zaman vardır: Geçmiştekilere ilişkin şimdiki zaman, şimdikilere ilişkin şimdiki zaman ve gelecektekilere ilişkin şimdiki zaman.' Çünkü bu üç zaman zihinde vardır ve onları başka yerde görmem: Geçmiştekilere ilişkin şimdiki zaman anı, şimdikilere ilişkin şimdiki zaman bir anlık görü, gelecektekilere ilişkin şimdiki zaman da beklenti olarak vardır." 33

\section{DİNIN KURUMLAŞMASI VE ZiHNiYET}

\section{A. Kilisenin Doğuşu ve Akaid}

Zengin dinî ve dindışı esatir, bütünüyle birer yahudi olan ilk Hıristiyanların da taşıdığ bilgilerdir; dünyayı tanzim ve kaostan kurtuluş konusunda hiçbir hüküm taşımayan Yeni Ahid eksikliğini Eski Ahid ile giderir. İsrail oğulları tarihinin etkisiyle birbirleriye örüntülü bir anlamlar dünyasına dönüşmüş bilgiler, azizlere yeni dinlerini yayarlarken zihnen eşlik ederler. Hıristiyanlık, başlangıcından itibaren, yerleşik düzene karşı itaatkârdır; havariler, önce yahudiler arasında İsa'nın tebliğini sözle tekrarlar; ama daha çok Eski Ahid'den metinler okurlar... Halka genişledikçe müntesipler çoğalır; şakirtler dinlerini şifahi bir zeminde yayarlar; oldukça avamîleştirilmiş bu tebliğ tarzı, farklı kültürlere sahip topluluklara Hıristiyanlığın tebliğini kolaylaştırır.

Aziz Paulus'un, artık Hıristiyanların yalnızca Yahudilerden oluşmadığını ve yeni Hıristiyanların Yahudiliği bilmek gibi bir mecburiyetleri olmadığını söylemesiyle, Hıristiyanlığın yayılması daha kolaylaşmıştır. Hıristiyanlık, İsrailoğulları'ndan bağlarını koparır $^{34}$ ve israiliyat etkisinde oluşan ilk kilise kaybolur; Anadolu’ya, Roma ve Avrupa'ya geçer. Bu geçiş kolay olmamış, önce Hıristiyanları katleden Roma, sonradan Hıristiyanlığı devlet dini olarak kabul etmiştir. Doğulu ve tektanrılı bir dinin, Roma eliyle batıya aktarılması, bugünkü Avrupa'nın kültür temellerini oluşturur.

Eski Ahid'in yazıya geçirilişine benzer bir süreç, Yeni Ahid'in toplanışında da yaşanmıştır. Hatta, Hıristiyanlar İsa’ya bir kitap indirilmediğine, İsanın söylediklerinin bizzat Tanrı kelamı olduğuna inandıkları için farklı dillerle yazılan İnciller, değişik kültürlerden iktibaslara açıktırlar. Önce Helenizmle uylaşarak ortalama bir din oluşturan Romanın Hıristiyanlığa geçişi, yine bir uylaşmak olmuştur. Helenistik Roma’nın baskın kültürleri, din üzerinde daima müdahil bir güç olmuş ve yazılı kaynakların yayılmasından çok önce sözlü bir Hıristiyanlık inancı oluşturmuşlardır.

Şifahi Hıristiyanlık, imparatorluğa hâkim kültür olan Helenizmin dini edebiyatı ve kültür

İstanbul: Remzi Kitabevi, 2000.

33. Zaman Kavramı (Aristoteles/ Augustınus/Heıdeger), çev.Saffet Babür, Ankara: İmge Kitabevi, 1996, s. 55.

34 .Yeni Ahid'in en eski yazılı metinleri olmak itibariyle Paulus'un Mektupları, Hristiyanlık akidesinin temelini oluş̧urmuştur. Gerçekte Yunan kültürüyle yetişmiş, iyi bir eğitim almış ve birçok dini inancin terminolojisinden haberdar biri ve Roma vatandaşı olan Paulus, İsa’nın mesajının yalnız yahudilere değil bütün insanlığa olduğunu yayar ve Hristiyanlığın Yahudilikten ayrılarak ayrı bir din haline gelişinin yollarını açar. Dört İncil yokken, onun mektupları birçok kavme ulaşmakla kalmayıp; bizzat kendisi misyonerlik yaparak Hristiyanlığı farklı kavimlere ve kültürlere tebliğ eder. Ölümünden sonra, Hıristiyanlık artık Eski Ahid ile amel eden İlk Kilisenin sınırlarını taşmış ve farklı hristiyan toplulukları, Paulus'un sözleriyle amel etmiş, İncil'in diğer metinleri sonradan ortaya çıkmıştır. ( Suat Yıldırım, Mevcut Kaynaklara Göre Hristiyanlık, Ankara: DİB Yayınları, 1988) 
1stılahları ile beslenmiş, Özellikle Paulus, yayılmaya başlayan bu taze dini önce Yahudiliğin gölgesinden kurtarmış; sonra, işlek helen medeniyetinin çoktanrılılığına hitap eden bir tebliğ usülü geliştirmiştir ${ }^{35}$. Yahudiliğin varmış olduğu tevhid anlayışı, Helen ve Roma ikliminde kırılmaya uğramıştır; kendisine kitap indirilmediğine inanıldığı halde, Hz. İsa'ya dayandırılarak yürütülen teolojik çabalar; İncil metinlerinde yalnızca iki yerde ${ }^{36}$ geçmesine rağmen teslisi köklü bir inanç haline getirmiştir. Kesin bir mutabakat sağlanamayan ve üzerine kurulan tartışmalarla esrarlı, cerbezeli ve tanrı ile insan ilişkisi konusunda farklı çağrışımlara açık bir teoloji konusu haline getirilmiştir ${ }^{37}$. Şifahi zeminde ağızdan ağıza yayılan teslis, İznik Konsilinde (325) henüz resmileşmemiştir; Konstantinapolis Konsilinde(533) ise resmen Hıristiyan akaidinden sayılmıştır. Din, Roma için siyasi birliği sağlamanın bir aracı görülmüş ve bu tanınma ve müesseseleşme, zihnen esnek ve ikircikli bir yapıya sahip Yeni Hıristiyanlığı rahatsız etmemiştir.

\section{B. Dünyevîlik ve Kilise}

Kilisenin İncil'den ve akaidden önce teşekkülü, Hıristiyanlığı başlangıcından itibaren dünyevileşme (sekulerizm) nin içerisine çekmiştir. Başlangıçta dünyalık işlerin yürütümesi hususunda tamamen Eski Ahit'e bağlı kalan Hıristiyanlar, helenleşme ve Roma lİsansına kavuşma sürecinde, yeni kavimlere tebliği kolaylaştırmak amacıyla Yahudilikten ayrılmaya başladılar. Eski Ahidin sayfalarının Hıristiyan teologlarca tefsiri, tevhidin teslise dönüştürülmesi, yahudi geleneklerinden kısmî vazgeçmeler hep aynı sürecin tamamlayıcılarıdır.

Tevrat ravîlerine atfedilen tanrı ilhamına sahip olmak özelliği, Hiristiyanlarda daha ileri götürülmüştür. Çünkü Tevratın ilk beş bölümü doğrudan doğruya Hz. Musa'ya vâhyedilen kitap olduğuna inanılır; oysa, Hz. İsaya kitap indirilmemiş, Rab doğrudan doğruya İsalaşarak (tecessüd), konuşmuştur. İncil yazıcıları, Hıristiyan teologlar da aynı biçimde peygamberî ilham sahibi olup, ne söylerlerse haktan söylerler. Bu yüzden batı zihniyeti üzerinde, dünyevîleşmenin ilk mümessili olan kilise kurumunun mutlak bir etkisinin varolduğu söylenebilir: Hıristiyanlık, saf dinleşme sürecini ilk Kilise zamanında tamamlamıştır; helenistik yorum ve Roma Hıristiyanlığının kıtalararası yayıldığı dönem olmasına rağmen; batnında sekülerleşmeyi taşır ${ }^{38}$. Çünkü kilise dünyevî alana hâkim güçlerin kendini biçimlendirmesine karşı çıkmak bir yana, onaylamış; seküler safhada teşekkül eden kilise, tamamen dünyevî değişkenlere bağımlı olguların etkisindeki buyruklarını bir din olarak yeniden tanzim etmiştir. Roma ile Hıristiyanlık arasında gelişen,

35 . Paulus'un hayatı ve yaptıkları hakkında geniş bilgi için: Doç. Dr. Suat Yıldırım, age..)

36. Matta, Bab:III, 16-17.; Yuhanna, Bab:I, 32-34

37 .Benzer teslisler Babil, İran, Yunan, Hint dinlerinde de vardır. Ancak, hristiyanlığın doğuşundan çok sonra Tanrının hakikati hakkında varılan kesin yargı haline getirilen Teslis, Olimpos kökenli gibi gözükür; Hz.İsa bir yönüyle Oziris, bir yönüyle Prometheus gibidir; Ruhü’l Kudüs'ün ise tanrıların Kutsal Ateşine benzemesinin bir yakıştırmadan daha fazla bir benzerlik olduğunu düşünüyoruz. Nihayet esrarengiz teslis hakkında Katolik teolog’un sözleri:"Hristiyan düşünürleri her çağda, Üçlü birliğin gizini ifade etme çabalarında, çağlarına özgü filozofik kavram ve sistemleri kullanmaya çalışmışlardır. Kilise konsilleri ve papalar bazı özgül formülleştirmelerin yanlış olduğunu ifade etmekle birlikte, gerçek hristiyan öğretisini kendi beyanları ile sınırlandırmamışlardır.'(Thomas Michel, age.., s.68). Bizim için teslis'in saçma ya da makul olması tartışması değil, işlevi önemlidir.

38. Vergi almak devlete, vermek tebaaya mahsustur... Ferisilerin Romalılara vergi verilir mi sorusuna Hz. İsa “ Kayserin şeylerini kaysere, ve Allah'ın şeylerini Allah'a ödeyin...” cevabını verir.(Matta, Bab:XXII, 21). Hristiyanlarla devlet(Roma) arasında ilişkiler açısından Yeni Ahid'in çizdiği çerçeve ilginç:"Herkes, üzerinde olan hükümetlere tabi olsun; Çünkü, Allah tarafından olmayan hükümet yoktur; ve olanlar Allah tarafindan tanzim olunmuştur. Bundan dolayı hükûmete mukavemet eden Allahın tertibine karşı durmuş olur; ve karşı duranlar kendi aleyhlerine hüküm alırlar...." (Romalılar, Bab:XII, 1-2). Devamı boyunca bu Yeni Ahid satırları, Romalılarla imzalanan bir antlaşma gibi sürer. Güce karşı bu genel hükümler ve tarih boyunca Kilise'nin iktidar ile iliş̧kileri, dinleşme ve sekülerleşmenin diyalektik akışı hakkında bilgi vericidir. 
iktidarın paylaşımı olgusu hem Hıristiyanlığın din olarak biçimlenmesi hem de Hıristiyanlığın biçimlenmiş şeklinin Katolik Kilisesi tarafından resmîleştirilmesidir.

Katolikliğin resmîleşmesi, Roma sonrasının (Orta Çağın) sekülerleşmesidir. Orta Çağ sekülarizasyonu, her ne kadar dinin egemenliğinde geçen bir çağ olarak değerlendirilse de; için için dünyevî alanı tanzim eden ve Avrupa bütünlüğünü koruyan ve geliştiren bir medeniyet biçimi olarak değerlendirilmesi daha doğru olur. Bütün bunlar bir araya getirilince; Batı zihniyetinin teşekkülünü anlamada İncil metinlerinden çok, Kilisenin hareketlerinin ve konuşlandırılış biçiminin ve işlevinin anlaşılmasının daha öncelikli olduğunu söyleyebiliriz. Çünkü kilise, Hıristiyanların inancına göre Tanrının Kutsal Ruhu tarafından yönetilmektedir ${ }^{39}$.

İlk Kiliseden Hıristiyanlığın kurumlaşmasına ve Roma yoluyla günümüze kadar geçen dönem içerisinde Tanrı, insan, Tabiat anlayışlarının yeniden gözden geçirilerek yaşanagelen oluşum ve dönüşümlerin ortak tarafı, teolojik bir çıkışla başlaması ve dünyevî alanın yeni bir muhtevaya ulaşmasıdır. Kilise mensupları bilginin sahibi ve üreticisi olarak dönüşümlerin başlamasında birinci derecede rol oynarken; iktidarın bir parçası olarak Kilise, olanca direncini gösterir ve herşey Tanrı adına yapılır. Yahudilerin aşkınlaştırma ve tenzih yolu ile israiloğluna yakın, başkalarına ve tabiata uzak bir tarihi olgu gibi algıladıkları Tanrı; Roma ve helenizmin etkisine giren Hıristiyanlarca, kilisenin tarihine emanet edilmiştir. Beşerî zaaflaarla dolu HelenRoma tanrılarının tersine zaaflardan uzak tek Tanrı ile karşılaşan yeni dinin mensupları için çıkış yolu insanın yarı tanrılaştırılması olmuştur. "Hıristiyanlar, Hz. İsa' da sadece Allah'ın naibi saltanatını değil, Allah'ın oğlunu da gördüler ve hatta onun(...) Tanrıya eşit olduğunu beyan edecek kadar ileri gittiler.(...) üstün bir dinin kurucusu bizzat Tanrının kendisi olarak telakki edilmiş veya edilmemiş de olsa beşerüstü bir otorite sahibi olarak kabul edilir ve bu dünyadan göç ettikten sonra bu otoriteyi mirasının ebedî bir emanetçisine devrettiğine inanılır"40. Kilise, Kutsal Ruh tarafından yönetilir ve hâtâdan arındırılmıştır; gerçekte, hatadan arındırılmış olan kilise mensupları ya da teologlardır, bir müessese olarak kilisenin rolü ise, inananlar üzerinde denetim gücünü artırmaktır. Bu uygulamaların bir devamı olarak, kiliseye karşı yürütülen hareketler, yine kilise içerisinden çıkmış azizler tarafından yürütülmüş; bir karar noktasına varıldıktan sonra ise kutsama ve tasdik etme işi yine kiliseye düşmüştür.

\section{Milatlaştırma ve Yeni Bir Tarih}

Milatlaştırma, zamanın kısa tarihini yazmak için başvurulan ve evrimci yaklaşımla bütünleşen bir anlayış olarak, batı zihniyetinin önemli bir özelliğidir. Zamanın muayyen bir kesitinde yaşanan ve şifahi zeminde gerçekleştikten çok sonra, yazıya geçirilen ve resmiyete kavuşan herhangi bir başlangıç noktası, önceyi ve sonrayı aydınlatan projeksiyonlarla ve istidracî bir yöntem ${ }^{41}$ izleyerek mutlaklaştırılır. Hz. İsa'nın Doğumunun gerçekleştiği andan çok sonra zamanın kısa tarihi için, itibari bir başlangıç kabul edilmesi de hem Roma hem de Hıristiyanlığın tarih anlayışını derinden etkilemiştir. Yahudiler için, İsrailoğulları'nın tarihi, zaman bilincinin temelini oluştururken; Batı, Hz. İsa ile başlayan dönemi, Hıristiyanlık (tabiatiyle Avrupa) merkezli bir zaman bilinci geliştirmiştir. Bu zaman bilinci dairesinde, Hıristiyanlığın resmen kabulü ve milatlaştırma, adeta vaftiz edilen Roma-Helen medeniyetinin ihtişamlı zamanları Altın Çağ olarak

39. Michel, s. 68.

40 . Toynbee, Tarihçi Açısından Din, 182-183.

41 . İstidracî Yöntem: Varlık hakkında bilinenleri varlığın hakikati saymak; tarih içersinde yaşananları zamanın kendisi saymak suretiyle zamanı ve mekânı kayıt altına alarak eşya üzerindeki tasarruf hakkını mutlaklaştırmak. 
kabul edilmiştir ${ }^{42}$.

Tüccar Helenistikler; tabiî iktisadın ve onun bir parçası olan ticaret serbestliğinin varolduğu Doğu dünyasının bir parçasıdır. Akdenizin parayı, senedi, deniz nakliyatını, bürokrasiyi tanıyan ikliminin Greklere sağladığı bir üstünlük de kültürlerarası temas ve etkileşime açıklıktır; helenizmin oluşması ve yayılmasında bu iktisadî ahlakın rolü büyüktür. Roma ise imparatorlukların pek çoğu gibi fetihçidir, toprağa büyük önem verir; elde edilen topraklar büyük çiftlikler olarak paylaşılır ve fethin diğer bir kazancı olan ucuz köle emeğiyle işletilir.

\section{D."Altın Çağ’’dan Çıkış ve Kilisenin iktisadîleşmesi}

Geniş topraklar ve çok sayıda köle, Roma iktisadına hâkim rengini verir; Germen istilası sonrasında ticaret, şehirlerin gelirlerine $2 / 3$ gibi oranlara varan vergilerle el konulmasından sonra dinamizmini yitirmiştir ${ }^{43}$. Altın Çağ olarak kabul edilen Roma imparatorluğunun çöküşü, hiçbir zaman onun batıya kazandırdığ 1 değerleri sarsmamış, tersine onu yıkmakta bir dış amil olan barbarlar ondan etkilenerek Romalılığı Avrupa'nın kalbine yerleştirmişlerdir ${ }^{44}$. İmparatorluk yıkıldığında ve feodalite bütün uzuvlarıyla belirdiğinde, ${ }^{45}$ arda kalan: Coğrafi sınırları açığa çıkan bir Avrupa ve İbrani, Grek, ürünü bir Hıristiyanlığın hâkim kültür olarak baskın hale gelişidir. ${ }^{46}$ Avrupalı tarihçiler, Altın Çağ'dan sonra feodal dönemin gelişini iki şekilde yorumlarlar: Katolik tarihçiler için feodal dönemler, "Tanyeri’ nin A ğardığı” çağlardır, çünkü batı dine girmiş, Hıristiyan medeniyeti kurulmuştur; dinle ilgisini kesenler için ise vahşetin çağlarıdır.

$\mathrm{Bu}$ iki yaklaşım tarzından ilki, bir Avrupa Tarihi inşa etmenin zihni dayanaklarını oluşturur; ikincisi, modern medeniyetin yüceltilmesine yöneliktir. İki yaklaşımın aynı anda iç içe yaşaması Avrupa toplumlarını hâlâ kültür sahibi kılmaktadır. Gerçekte: Vahşetin tarihi yazılacak olsa, sömürgelerde uygulananların Orta Çağa mal edilemeyeceği, sanatın tarihi yazılacak olsa resimde değil ama, ev eşyalarındaki Orta Çağ ustalarının yakaladığı incelikler Rönesans'a mal edilemez. Hıristiyanlığın en büyük yenileşme hareketini gerçekleştiren bir Aziz Paulus’un, bir Aziz Augustin'in reform döneminde yaşamadığı herkesçe bilinir. Hangisinin tarihi değiştirmekte, nasıl roller yerine getirdiğini mutlak anlamda tayin etmek de imkânsızdır; ancak, tarihe bakıştaki farklılıklar kadar, toplumlarda tarihî devamlılık düşüncesini diri tutan ve pek çoğu irrasyonel olan dinamikleri anlamaya çalışabiliriz. İrrasyonel dinamikleri tahrip olan toplumlar kültürel bir varlık olmaktan çıkar, sömürgeleşir.

Keskin hatlarıyla belirtmek gerekirse, feodalizmin temel özellikleri: toprağın servetin

42. Roma’yı “Altın Çağ” Kılan sebepler konusunda: Chrıstopher Dawson, Batının Oluşumu, s.45-46.

43 . Mehmet Ali Kılıçbay, Feodalite Ve Klasik Dönem Osmanlı Üretim Tarzı, Ankara: Teori Yayınları, 1985,s.96.

44. Barbarlar ve Germenler hiçbir zaman Roma'yı aşacak bir sistem ortaya koyamamışlardır. Buna rağmen Roma, bütün haşmetiyle onlar için bir örnek mektep olmaya devam etmiştir (Chrıstopher Dawson, BatınınOluşumu, s.108.).

45 . Tanımı ve sınırları üzerinde tam bir mutabakata varılamayan, Feodalite; İktisadî uygalamalar, siyasi örgütlenme ve sosyal tabakalaşma açısından Avrupa topraklarında varoluş biçimiyle de farklılıklar taşır ve aynı anda ortaya çıkmamıştır. Fakat, merkez ve model olarak serfliğin ortaya çıkışı manor sisteminin gelişimi Kuzey Fransa ve komşu muhitlerinde olmuştu; Almanya'da kuzeyde ve İngiltere'de feodalizmin oluşumu gecikmelidir. (Selim Somçağ, Avrupa Feodalizminin Evrimi, İstanbul: Bağlam Yayınları,s.16-17). Feodalite'nin belli şartlarda ortaya çıkmasının zaruret gibi gösterilmesi, yanlış olur; çünkü İngiltere'de feodalizm, daha önce Avrupa'da bilinen bir model üzerine oturtulmuştur. Avrupa İktİsat tarihi yazımının müşterek grameri haline geldiği biçimiyle Feodalite, Roma ile Modern çağı birbirine kavuşturan zorunlu bir dönem sayılır. Böyle bir kabulün, arkasında yatan gerçek, Roma’nın Helenistik Hristiyanlığı, batının ortak kültürü haline getirmesidir; muhtemelen bu kültürel alt yapı, bir tarihî siyasi ve iktisadî sistem olan Feodalizmi karanlık olarak nitelendirilen çağlar için bir çözüm olarak Avrupa'nın hayatına sokar.

46 . Somçă̆ s.33. 
yegâne kaynağ 1 olması, kentlerin gerilemesi ve ticaretin zayıflamas $1^{47}$ ile kölecilikten serf-senyör arasında akitleşmeye geçiş üzerine inşa edilen bir hukukîliktir ${ }^{48}$. Siyasî açıdan, merkez fikrinin fersizliği ve bölünmüşlük var gibi görülmesine rağmen; Kilise tüm Orta Çağ boyunca örgütlü tek güç olarak kalmıştır. Kilise'nin manastır tecrübesiyle kazandığı mukavemet ve kabiliyet; kültürel zeminde, Avrupa'nın zihniyet benzeşikliklerini ve dönüşümlerini kolaylaştırmıştır. Kraldan senyörlere doğru bir silsileye rağmen, Haçlı Seferleri dışında kurulamayan bütünlük vardır ama Roma'dan arda kalan dünyada senyörlüklerin bir çözülmüşlük olarak değerlendirilebileceği gibi, çözülmeye karşı geliştirilen bir yaşama mücadelesi olarak da değerlendirilebilir. Her feodal bölge, kendi içinde canının istediği gibi serpilme imkânını bulmuş; "güçlü birer kişilik olarak bilinçli birimler halinde ve ülkesiyle bağımsızlığını savunmaya hazır..." " örgütlü topluluk modeli oluşturmuştur.

Bir tarihî dönemi iktisadî, siyasî ya da kültürel açılardan ele alırken peydahlanan kopukluk ve çelişkiler, genellemelere ulaşmada en büyük engeldir; ancak, geçmiş için bütün farklılıklara rağmen bir Avrupa Feodalizminden, bugün için bir Avrupa Kapitalizminden söz ediliyor ve âdetâ bir alışkanlı $\mathrm{k}^{50}$ halinde sürdürülüyorsa, bunu sağlayan zihniyet dünyasının temellerine yönelmek gerektir. Orta Çağı bu açıdan, yollarını Roma imparatorluğunun açtığı Helenistik-Hıristiyanlığın, Avrupa sathında mayalandığı dönem ${ }^{51}$ olarak değerlendirebiliriz. Aziz Augustine, Roma köleciliğgini, Hıristiyanlığa takdis ettirirken ${ }^{52}$; Orta Çağın rahipleri, feodal hukukun yürümesinde yargı görevini yürütmüşler, kilisenin hakkını da fazlasıyla gözetmişlerdir. Senyörün hakkı senyöre, serfinki serfe, Kiliseninki kiliseye... Sezar (iktidar sahipleri) ile Tanrı (Kilise) arasında, hukuken tasdik edilmiş bir sosyal tabakanın (serf) yer alması; Roma'dan bugünki batı medeniyetine geçişte şüphesiz kuvvetli bir zemin oluşturmaktadır. Serf'likten burjuvalığa geçiş; tanzimin, kutsallaştırmanın burjuvaca yapılması kapitalizmin doğuş sürecinin tarihî bağlantılarıdır.

Günümüzde milletlerarası para, banka, sermaye, borsa, kara para denetimi gibi iktisadî iş ve işlemleri yürüten kurumların yapısının ise tek karşıllı̆ı olabilir: iktİsadın kiliseleştirilmesi. Batı Uygarlı̆̆ı'nın son paylaştırması -kendini paylaştırma olmaktan çıkıp yeryüzünü paylaştırmaya dönüşen gücü- karşısında insanların, ülkelerin büyük bir bölümü bu örgütlü güç karşısında çaresizdir.

\section{IV. İSLAM TOPLUMLARI İLE BATI ARASINDA TEMEL FARKLAR VE SONUÇLARI}

\section{A. Tanrının Birliği ve Kozmik Birliğe Geçiş}

Gerçekte, Eski Ahid ve Kur'an, ilk insan'ın yaradılışıla beraber tevhidin yalnızca tasdik

47. Kılıçbay, s.145.

48. VI. yy'den itibaren, serfin sadakatini, senyörün serfi doyurma ve korumasını akde bağlayan sözleşmeler feodalitenin hukukî temelini oluşturmuştur.

49. Fernand Braudel, Uygarlıkların Grameri, çev. M.Ali Kılıçbay, Ankara: İmge Kitabevi, 1996, s.330.

50 . Jean Baechler, Kapitalizmin Kökenleri, çev. M.Ali Kılıçbay, Ankara: İmge Kitabevi, 1986, s.13-16.

51 . Siyasal bölünmüşlük ve geçirimsizliğe rağmen, Orta Çağ bir uygarlık ve kültür özdeşliğinin yaşandığı çağdır. Hac ya da iş yolculuğuna çıkmış bir yolcu, Lubeck’te olduğu kadar Paniste, Londrada, Brugesde; Kolonya kadar Burgos, Milano veya Venedikte kendini evinde hissetmektedir... Kavgalar, isyanlar ve çatışmalar ne olursa olsun; dini , ahlakî değerler; savaş, aşk, ölüm üzerine geliştirilmiş külttürel değerler bir fieften diğerine her köşede aynıdır... Adına şövalyelik uygarlığı denilebilecek bir tek uygarlık vardır; Haçlı Seferleri de çok sayıda vatanın hepsinde varolan ortak tutku ve maceraların yekvücut hale gelişini temsil etmektedir. (Fernand Braudel, Uygarlıkların Grameri, s.330-331).

52 . Augustine, köleliğin ilk günahın tabii sonucu olduğunu savunur ve savaş esirlerinin de köleleştirilebileceğine -kilisenin dünyevî sesi olarak- fetva verir (Vural Fuat Savaş, İktisatın Tarihi, s.113.) 
değil, teslimiyet noktasında bir inananın vasfı olması gereğini de yalın ve çarpıcı bir misal olarak: iblis'in Tanrı'nın birliğini tasdik noktasında şüpheden uzak olmasına rağmen, teslimiyet noktasında sergilediği itiraz çerçevesinde sebep ve sonuçlarıyla beyan etmektedir. İtiraz, Tanrının birliğine inanmada değil, kendisinin yaratılan başkalarından -Adem'den- üstün olduğu iddiasıyla Tanrının buyruklarına karşı gelmekle sonuçlanır. Düalite başlar; kozmos ile kaos iç içe yaşayacaktır.

Müslümanlara göre tevhid anlayışı, sözlü kültürlerden ve dinî metinlerden tamamen ayrı bir zeminde gerçekleşir. Şahsiyet olarak İslam peygamberi çocukluğundan itibaren Mekke'de hüküm süren şifahî ve yaygın putperestlik tesirlerinden uzak kalmış ${ }^{53}$; ümmî olmak itibariyle de ehl-i kitabın kutsal metinlerinden bağımsız bir kültür ortamında yetişmiştir ${ }^{54}$. Hz. Muhammed'in geçmiş zamanlara doğru, eski dinî esatirden, yaşadığı an parçasında ise Mekke şirkinden bağımsız olarak gelişen kişiliği, onun şüphesiz Kur'anın mesajını özgün anlamasına ve aktarmasına zemin teşkil eder. Kur'an'ın ilk emriyle beraber ${ }^{55}$, tevhid anlayışı da belirginleşir, zamanın ve insanın tarihi yeniden okunmaktadır: Kerem sahibi Rabb, insanoğluna kalemle öğretmiş, bilmediğini bildirmiştir; ancak, teslimiyet hususunda insanoğlu kendini üstün sayarak, azgınlık etmektedir. Bu hükümler, bütün kavmî hesapların çok üzerinde ve insanla Tanrı arasındaki birlenen ve birleyen bağını tayin edicidir. Çünkü İslamın doğduğu günlerde de tek tanrıya iman vardır ama kutsal metinlerin bilginler eliyle defalarca yeni bakış açılarıyla tanzimi, yahudi ve Hıristiyan zihinleri tereddüde sevk etmiş; din, bilginler eliyle, -çoğu kez de farkında olunmadan- dünyevileştirilmiş ve Tanrının birliğine imanın kayıtsız şartsızlığına rağmen, bildirdiğine olan samimi bağlılıkta gedikler açılmıştır. Mekke, neredeyse, bütün Sami dünyasınca maruf Allah’ı bilmesine rağmen, kendi gündelik hayatlarını tanzim kastıyla tanrılar üreten insanların şehri haline gelmiştir. İslamî tevhid inancı, hem semavî dinlerde meydana gelen teslimiyet noksanlığına, hem de şirke karşı en uygun cevabı vermek zorundadır: bu cevap, "lâ-ilâhe illallah"(ilahlar yok, yalnızca Allah vardır) olmuştur. Bu mesaj ehl-i kitabın da müşriklerin de zihnen anladığı basitlikte (simple) ${ }^{56}$ bir inşaya sahiptir. Ehl-i kitap (Yahudi ve Huristiyanlar) varolan bilgisiyle, Hz. Muhammed' in ilettiği haberin İbrahimî köklerini hissetmiş ve büyük bir bölümü bunu bir meydan okuma kabul ederek hasımane

53. Bütün tarihi kaynakların bildirdiğine göre Hz. Muhammed, doğmadan önce babasını, altı yaşında da annesini kaybetmiştir. Şahsiyetin temel özelliklerinin oluştuğu ilk çocukluk yıllarında o, süt annesinin gözetiminde, Mekkeden uzak bir tabii ortamda yetişmiştir. Şüphesiz, islam inancına göre bütün peygamberlerin hayatı, Allahın görevlendirdiği kişiler olmaları münasebetiyle muhafaza altındadır. Hz. Musa ve Hz.Davud gibi pekçoğu da nübüvvetten önce çobanlıkla iştigal etmişlerdir ve bu durum da onlara şahsiyetlerinin teşekkülü noktasında temiz bir çevre, saf bir zihin kazandırmıştır. (Abdullah Draz, Kur'an’ın Anlaşılmasına Doğru, çev. Salih Akdemir, Ankara: Mim Yayınları,1983, s.9-26)

54 . Batılı teologlar için peygamberlik görevinin, islam inancından farklı bir yanı vardır. Yahudiler olsun hristiyanlar olsun mukaddes metinlerinin alimler tarafından sonradan oluşturulduğu hususunda hem fikirdirler. Kur'an, bu durumu doğrular, Tevratın ve İncilin korunması ve aktarılması alimlerin görevi olmuştur; ancak alimler kitaplara kendilerinden birtakım ilavelerde bulunmuşlardır ve ortaya zaman zaman birbiriyle çelişen vahyî metinler ortaya çıkmıştır. Yahudi ve hristiyan ulema, peygamberlerinin tebliğini hıfz, yaşama ve aktarma noktasında tıpkı peygamberler gibi masumiyet sıfatına sahiptirler; bu ise ilk tebliğden sonra peygamberlerin görevini sona erdirici bir mahiyet taşır ve ulema peygamberî görevi bizzat üstlenir. Böylesi bir gelenek içinde yetişmiş batılı teolog ve tarihçiler, Hz. Muhammedin peygamberliğini de kendi zaviyelerinde değerlendirerek, Kur'anın Eski ve Yeni Ahid gibi, bilginler tarafından tebyin edildiğini anlamaya meyillidirler; Hz. Muhammedin ümmîliğini de kabul etmekte zorlanırlar; ancak, Kur'an’ın ilk mesajı bunu teyit edicidir ve müslümanların bu husustaki şeksiz şüphesiz inançları, sosyolojik açıdan bütün tarihi ve teolojik değerlendirmelerin ötesindedir ve kendi sonuçlarını da doğurmuştur.

55 . "İkra", yani "Oku!"

56. Gibbon, bu durumu "Muhammed'in getirdiği din, Zerdüşt'ün sisteminden daha saf, daha temiz, Musa'nın yasalarından daha yumuşak, yedinci yüzyılda İncilin sadeliğini bozan batıl ve esrarengiz inançlardan daha makul ve daha insicamlıdır.” sözleri ile ifade eder. (M. A. Mannan, İslam Ekonomisi, çev. Bahri Zengin, İstanbul: Fikir Yayınlar1, 1976, s. 27.) 
bir tavır takınmış; bazıları ise yeni dine tabi olmuştur ${ }^{57}$.

"La-ilahe..." çağrısının tanrının birliğini tasdik noktasında kalmayıp, evreni tasavvur ve doğa ile ilişkiler noktasında kozmik birliğin de ${ }^{58}$ temelidir ve herhangi bir kültürel kırılmaya uğramamıştır. Kozmoloji, canlı cansız bütün varlıkların kendi lisanlarınca Allah'a kulluk etmede oldukları temeline dayanır; yani kaos (karışıklık), Tanrının birliğine yönelmiş bir düzenliliğe sahiptir. Kulların birbirlerine karşı sorumluluk ve davranışlarının temel ilkeleri ise peygamberler vasıtasıyla insanlara nakledilmiştir. Hz. Muhammed (Kur'an); Yahudi ve Hıristiyan iddialarının kendilerini merkezileştiren tavırlarına karşın, Hz. İbrahim'i ve diğer peygamberleri kavmî liderler, tarihî dönemlerle sınırlı vazifeliler olarak göstermemiş; ilkiyle, sonuyla zamanın tamamını kuşatan ilkeleri bütün insanlara ulaştıran elçiler olarak kabul etmiştir. Tevhid inancı, peygamberlerin getirmiş olduğu ölçülere teslimiyet noktasında Tanrı-peygamber-insan silsilesiyle tamamlayarak tereddüde mahal bırakmamış; evrendeki herşeyin kulluk çerçevesine yerleştirilmesi ise insaninsan ilişkilerinin ve doğayı tasarrufun sınırlarını belirlemiştir. Besmele ise en üst derecede bilgi üretiminden, en alt derecede günlük hayatın rutini gibi gözüken faaliyet alanlarını, Allah ile irtibatlandıran, mümini meşruiyete çağıran ve insana halifelik görevinin verilmesini hayatın her safhasında hissettiren kozmolojik bir anahtar hüviyetindedir ${ }^{59}$. Allahın ismi ile başlanmasında tereddüt görülen alan, evrenin düzeninde fesata yol açabilecektir; bu endişe, beşerî faaliyetlerin işleyişinde önemli bir rol oynamaktadır. Kuran'a göre Canlı cansız varlıklar içinden seçilerek insana verilen halifelik görevi ile diğer iki dinin metinlerinin insanı değerlendirişi arasındaki fark ${ }^{60}$ eşyayı tasarruf biçimini derinden etkiler.

\section{B. Peygamberlik ve Tarih Bilinci}

Kitab-1 Mukaddes'te sadece peygamberlerin naklettiklerinin değil, azizlerin şahsi tecrübelerinin de yer alması, Hıristiyan fundamentalitesinin Müslümanlıktan temel farkını oluşturur. Kabul, tarihin getirdiği bir mecburiyettir, çünkü, Kitab-1 Mukaddes ancak kronolojik İbrani-Hıristiyan tarihiyle beraber okunduğunda anlaşılabilir niteliktedir ve peygamberle nas arasında başkalarının olmasını kaçınılmaz kılmaktadır. Nitekim Yuhanna incilinin ilk ayetinden yola çıkarak getirmiş olduğu yorum istikametinde teslis akidesini reddeden ilahiyatçı Arius'un düşünceleri sonrasında kilise, Hıristiyan akidesinin yeniden yazılmasını ve daima hatırda tutulması için ayinlerde bir ibadet olarak tekrarını ${ }^{61}$ bir tedbir olarak getirmek zorunda kalmıştır. Tedbir, Kilise'nin akideye yaşanan olaylar istikametinde müdahale edebildiğini göstermektedir.

Kur'an'ın vahiy kâtiplerine yazdırılması ve indirilen ayetlerin ezberlenmesi ve bağlanması neredeyse eş-zamanlı gerçekleşmiştir. Şarkiyatçıların kendi dinî tecrübelerinin de tesiriyle

57. Fazlurrahman, İslam, çev. M. Dağ-M. Aydın, İstanbul: Selçuk Yayınları, Üçüncü baskı, 1993, s.36,37.

58 . Çünkü canlı cansız bütün varlıklar, lisan-1 hallerince Allah’ı birlemekte ve zikretmektedirler.(Kur'an, Hacc,18)

59. İslam Ansikopedisi, TDV Yay, Besmele maddesi

60. Kur'anî kavram olan halifelik ile Eski ve Yeni Ahid'in "Tanrının oğlu ve kızı" nı bazı hristiyan teologlar aynı şeyler gibi değerlendirmek eğilimindedirler. (age.., 7.Bölüm); ancak kutsal kitaplara bütün olarak bakıldığında(Bakara 2/30, En'âm 6/165, Neml 27/62, Sâd 38/26 "halifelik" konusunda çıkan anlam insanın Allah adına dünyayı tanzim görevi olduğudur. "Oğul”luk ise her insanın vasıl olamayacağı bir mertebedir(Yuhanna 15/15, İbranilere 3/5, Galatyalılara 4/7) ve diğer insanlardan yani kullardan ayrı birşeydir. Buradan hareketle, "oğul ve kız" mertebesinin aziz ve azize mertebesiyle, giderek kurum olarak "Kilise" ile örtüştürülmesi mümkündür. Eski Ahid'de geçen Tanrının oğullarının insanların kızlarına cinsel tacizde bulunması ve çocuk türetmeleri(Tekvin 6/1-8), "Tanrı oğlu ve kızı" kavramlarını iyice bulanıklaştırmaktadır.

61 . Ahmet Yüksel Özemre, İslamda Aklın Önemi Ve Sınırı, İstanbul: Denge Yayınları, 1996, s.192. 
Kur'anın da peygamber haricindeki şahısların da müdahalesine açık olduğu, en azından Hz. Muhammedin siyaset ve taktik icabı kendinden ilavelerde bulunduğu iddiaları süregelmiştir. Ancak, sahifelerin çok kısa bir sürede bağlanmış olması, bugünlere kadar süren derin bir hürmetle yazılı ve sözlü muhafazası ve "Tanrı kelâmı" olduğuna dair kesin inanç, tarihî açıdan kendi sonuçlarını Doğuracaktır. Mukaddes kitapların edebî ya da tarihî tenkitlerinin çıkış noktası da varış noktası da dinler arasındaki farklılıkların vurgulanmasından ibarettir; anlamaya çalışmamız gereken ise insanların hayatında sürdürdükleri zihnî etkilerdir.

Kur'an ayetleri kavimlerin, tarihî olayların, tarihî dönemlerin kronolojik sıralaması değildir; zira kronolojik zaman anlayışı, bir algılama kolaylığının tezahürüdür. Eski ve Yeni Ahid'in kayda alınması öncesi, ağızdan ağıza nakledilenleri yapan ulemanın kronolojiye düşkünlüğü, çatkılarının (inşalarının) inandırıcılık gayretinden başka birşey değildir; bu ise ilgileme (referans) noktalarının çeşitliliğine yol açar ve seçmece (eklektik) tavrı beraberinde getirir. Kutsal metinle, sonradan ilave olunanın hakemliği, kilise büyüklerine düştügü için, Hıristiyan teolojik geleneğiyle hem-zihin bir Batılının Kur'anın kronolojik bir olaylar derlemesi olmayışını, Ortadoğu'da kronolojik tarih anlayışlarının gelişmediğine ve dolayısıyla Hz. Muhammed'in Kur'an'ı bu gelenek doğrultusunda naklettiğine bağlaması anlaşılabilir mahiyettedir ${ }^{62}$. Ancak, İslam inanc1nın hilafına, peygamberin metni yazdıran şahsiyet olduğu düşünülecek olsa bile, Kur'an en azından Mekke ve Medine hayatının ayrıntılı hikâyesini kronolojik ve sebep sonuç ilişkileriyle verme imkânına Eski ve Yeni Ahid derleyicilerinden daha fazla sahiptir; çünkü ağızdan çıkışıyla kayda alınışı eş zamanlıdır ${ }^{63}$. Kuran'da böyle bir gayenin görülmeyişi, İslamın ve kitabının zaman anlayışında aranmalıdır. Zamana dair temel bilgi, şahısların, toplulukların tecrübelerinden tenzih edilmiş ontolojik bir mecrada gelişir. Mecra: öncesi Âdem ile başlayan vahiy; sonu ise yine Hz. Muhammed ile sona eren vahiy istikametinin topyekûn algılanmasıdır. Kur'an, evvel ile ahir arasındaki yaşayan ve yaşayacak olan insanların hayatlarını sürdürmeleri için lazım olan bilgileri peygamberler vasıtasıyla insanlara aktarıldığını beyan eder; geçmişe doğru kavimlerin, insanların, peygamberlerin hayatından bahsedilmesi, bunları biricik ve tekrarı mümkün olmayan olaylar olduğundan değil insanoğlunun geçmişteki ve gelecekteki hayatının mahiyetine dair olduğundandır. Bu kıssalar, Kur'an içerisinde çok az yer tutar; Kitab-1 Mukaddesin ise neredeyse tamamıdır. Oryantalistlerce yadırganan bir hâl de -iki yerde geçmiş olmasına rağmen- Kur'an da özel isimlerin olmadığı iddiasıdır ${ }^{64}$; bu hâl, onlara göre Kur'anın tarihi gerçekliğine gölge düşüren bir noksanlıktır.

Kur'an'a yöneltilen tenkitlerden hareket ederek, Kitab-1 Mukaddesin tarihi isim ve olaylarla desteklenmiş metinlerinin, batı sosyal bilim geleneğini, özellikle şematik tarih anlayışını beslediğini söylemek mümkün hale gelmektedir. Çünkü Esk-i Ahid'in kronolojik sıra ile bildirdiği peygamberler, kendi kavimlerinin tarihleriyle özdeşleştirilmişlerdir; Yahudilik, sosyal ve tarihî ifadesini yalnızca İsrailoğullarının pratiğinde bulmuştur. Hodgson'un ifade ettiği gibi Tevrat yazıcıları, “özellikle tarihteki manevi terakkinin-(şüphesiz bu gerçek anlamda terakki manasına gelmeyebilirdi) büyüleyici biçimde farkında olma yolunda mesafe kaydettiler." ${ }^{65}$ Ancak, peygamberlerin sosyal tarihin bir parçası gibi hareket ettikleri iddias ${ }^{66}{ }^{6}$ eksiktir ve Kitab-1

62 .Montgomery Watt, Günümüzde İslam ve Hristiyanlık, çev. Turan Koç, İstanbul: İz Yayınları,1991.

63. Fazlur Rahman, s.42.

64 . Prof. Dr. İsmail Cerrahoğlu, Hadis Usûlü, Ankara: DİB Yayınları,1979, s.65.

65 . Marshall G.S. Hodgson, İslamın Serüveni, Bir Dünya Medeniyetinde Bilinç Ve Tarih, İstanbul: İz Yayıncılık, 1995, s.50.

66. Montgomery Watt, Age.., s. 159-160. 
Mukaddes'te yazılan tarihin tesiriyle öne sürülmüşs sayılmalıdır; gerçekte bütün peygamberlerin insan ve dış dünyayı derinden kavrayıcı ve sonuçta insan ile dış dünya arasında kozmik bir düzen oluşturucu oldukları söylenebilir; çünkü peygamberler, bağlılarını maruz kaldıkları herhangi bir zorluk ya da darlıktan umulmadık anda kurtarmışlar ve bu mucizevî yönleriyle de sosyal tarihin imkânlarının sınırlarını aşmışlardır.

Eski ve Yeni Ahid'in kronolojik bir tarih metni gibi kaleme alınması, peygamberlerin tercihiyle gerçekleşmiş değildir; tersine peygamberliği zamanın bütününden tecrit ederek, herhangi bir tarihi vakıa derecesine indirgeyici olmuştur. Vakıalar İsrailoğulları'nda bir kavmin tarihine malzeme; Roma sonrası dinin biçimlenmesinde ise, Hıristiyanların dünyevî alan içerisinde kendine tahsis edilen sınırlarda meşruiyet dayanakları oluşturma aracı gibi kullanılmıştır. Hıristiyanlığın yahudilikten ve İslamdan büyük fark1, Hz. İsa'nın tebliğ ettiği dini, bir toplum ve devlet sistemi olarak inşa etmeden bu dünyadan göçmüş olmasıdır. Bunun sonucu, akaidin ideolojiye dönüşmesi, yani fundamental kayganlık olmuştur. Hıristiyanlığın hayatı tanzim edici güce ulaşması, Roma'nın kabul ve sınırlamaları çerçevesinde gerçekleşmiştir. Bu yüzden, tabiatla ve toplum hayatıyla ilgili uygulamalar sekülerizmle beraber gelişmiştir; bir yandan erken dönemde kökü yakın Doğu Babil toplumuna ulaşan Grek felsefesi ve yine yetkin bir örneğini Pitolomoler'de gördüğümüz köleci üretim tarzının ve bürokratik devlet teşkilatının varisi Roma imparatorluğu, Hıristiyanî dünya görüşünün genel hatlarını çizmiş ve bugünki batıya ulaşan bir çığır açmıştır.

Orta Çağ olarak nitelendirilen dönem bu çığı üstünde, Tanrı (Kilise) ve Kraldan başlayarak senyörler silsilesinin hükümranlığı paylaşmasının maceraları izlenmiş̧; serfler ise, St. Augustin'in teolojik felsefesinin temeli üzerine inşa edilen asgarî karın tokluğu hukuku diyebileceğimiz sınırlı özgürlük alanlarında kalan kitleler olmuştur.

\section{C. "Başkaları" ve Merkantilizm}

Tevhid, şüphesiz diğer İbrahimî dinlerde de Tanrı'nın varlık ve birliğini tasdik etmektir; ancak, tevhid inancındaki farklılıklar, tasdikin değil teslimiyetin sınırlarında ortaya çıkmaktadır. Musevilik, Hz. İbrahim'le başlayan ve temelinde kavmiyetçiliği barındıran bir dine dönüşünce; zaman içinde başlangıcı ve sonu olmayan Tanrı'ya iman da yalnızca İsrailoğulları'yla ezelî ve ebedî ahdi istikametinde tarihî müdahalelerle kendini hissettiren bir cemaat (kavim) tanrısına imana dönüştü.

Bu dönüşümün Yeni Ahid cephesi de Tanrının Hıristiyanlarla -Avrupa toplumlarıylaahdidir. Augustin'in Roma'nın dönüşümü esnasında geliştirmiş olduğu ve Orta Çağlar boyunca etkili Tanrı Devleti-Yeryüzü Devleti ayırımı, bir topluluğa ait tanrı fikrini de besleyicidir. Tüm vaftiz edilmiş Hıristiyanlar Gökyüzü devletinin ama aynı zamanda Yeryüzü Devletinin de tebaasıdır. Dil alanında önce İbranice kutsal metinlerden kopuş ve 18. yy. da Latince'nin mahalî diller içerisinde eritilişi uluslaşma hareketlerini beslemiştir. "Orta Çağ, düşünce ve sanat alanında derinlemesine bir şekilde uluslararası olmuştur. Ortak karakteristikleri olan geniş boyutlu bir Hıristiyan uygarlığ 1 , XIII. ve XIV. yüzyllardan itibaren tüm uygar Avrupa yüzeyini kaplamıştır"67. Latince gibi işlek bir ortak dilin yardımı, köklü kültür ıstılahları oluşturmuştur. "Tüm vaftiz edilmiş Hıristiyanlar" topluluk düzeyinde ulus birimlerinin temelini çatmış, aynı zamanda kuvvetli bir "başkaları" ayırımını da beslemiştir. Uluslaşmanın gerçekleşmesine rağmen, temelde paylaşılan kültür ıstılahları, ortak zihniyet alanı olarak Avrupa ülkelerini birbirine benzeştirmiştir.

67 . Lucien Febvre, Rönesans İnsanı, çev. M. A. Kılıçbay, Ankara: İmge Yayınları, 1995, s. 86-87. 


\section{Sonuç}

Müslümanlar İbrahimî geleneği kabul etmekle beraber, özellikle Osmanlılarda gördüğümüz ve halkın "İbrahim milletindenim!" ifadesindeki yaygın yanlışlık ve bulanıklık sürmüştür. Milletin Hz. Muhammed'e nisbet edilmeyişi ve "Hz. Muhammed'in milletindenim" denilmeyişi Kâtip Çelebi’ye yanlışlık olarak gözükür ${ }^{68}$. Yahudilerde ve Hıristiyanlarda gördügüüüz ve zaman zaman başkalarına karşı keskin bir biçimde geliştirilen biz ve başkaları din alanında başlamış, akaid haline gelmiş ve sonrasında tarihîleştirilmiştir. Bu durum Ortadoğu İslam dünyasında hiçbir zaman gelişmemiş, beraber yaşamak tercih edilmiştir. Osmanlıların Arapça ve Farsça kelimeleri Türkçenin kuvvetli varlığı içinde eritmiş olmalarına rağmen, "başkaları" düşüncesinin keskin ve ayırıcı bir nitelik taşımayışı, bugünkü anlamıyla uluslaşmayı engellemiş olabilir. Osmanlı toplumunda bir kültür farklılığı olarak çok net bir öteki düşüncesi gelişmemiştir; imparatorluğun kurucu unsuru olan Türkler'in "millî devlet" arayışları, ancak diğer unsurların kopuşlarıyla hız kazanmiştır.

Osmanlı'da merkantilist anlayışın gelişmeyişi, millet anlayışının batıdakine benzer bir tarihinin olmayışı, kendi dışındaki toplumların akaidi (fundamental) bir ilke olarak başkaları ve düşman olarak görmeyişiyle yakından alakalıdır. Merkantilizm ise bugünün hâkim ekonomisinin hazırlayıcısıdir.

\section{Kaynakça}

Augistinus, Aristoteles/Augustinus/Heidegger, Zaman Kavramı çev. Saffet Babür, Ankara: İmge Kitabevi, 1996.

Baechler, Jean, Kapitalizmin Kökenleri, çev. M.Ali Kılıçbay, Ankara: İmge Kitabevi, 1986.

Berger, Peter L., Dinin Sosyal Gerçekliği, çev. Ali Coşkun, İstanbul: İnsan Yayınları,1993. Braudel, Fernand, Uygarlıkların Grameri, çev. M.Ali Kılıçbay, Ankara: İmge Kitabevi, 1996.

Bucaille, Maurice, Tevrat Inciller ve Kuran, çev. M.Ali Sönmez, Ankara: DİB Yayınları, 1982.

Cerrahoğlu, İsmail, Hadis Usûlü, Ankara: DİB Yayınları,1979.

Cornell, Tim, Roma Ansiklopedisi, Atlas of the Roman World'un, çev. Şadan Karadeniz, İstanbul: İletişim Yayınları, 1988.

Çelebi, Katip, Mizanü'l Hakk Fi İhtiyar 'il Ahakk (En Doğruyu Seçmek İçin Hak Terazisi), Yayına hazırlayan: Orhan Şaik Gökyay, İstanbul: Tercüman1001 Temel Eser dizisi:1980, Yayın no: 145 .

Dawson, Chrıstopher, Batının Oluşumu, çev. Dinç Tayanç, İstanbul: Dergah Yayınları, 1976.

Doğan Özlem, Tarih Felsefesi, İstanbul: İnkılâp Yayınları, 2001.

Draz, Abdullah, Kur 'an ’ın Anlaşılmasına Doğru, çev. Salih Akdemir, Ankara: Mim Yayınları,1983. Fazlurrahman, İslam, çev. M. Dağ-M. Aydın, İstanbul: Selçuk Yayınları, Üçüncü baskı, 1993.

Febvre, Lucien, Rönesans İnsanı, çev. M. A. Kılıçbay, Ankara: İmge Yayınları, 1995.

Gökberk, Macit, Felsefe Tarihi, İstanbul: Remzi Kitabevi, 2000.

68 . Katip Çelebi, Mizanü’l Hakk Fi İhtiyar'il Ahakk (En Doğruyu Seçmek İçin Hak Terazisi), Yayına hazırlayan: Orhan Şaik Gökyay, İstanbul: Tercüman1001 Temel Eser dizisi:1980, Yayın no:145, s.89-101. 
Günaltay, Şemseddin, Türk Tarihinin Illk Devirlerinden Yakın şark- Elâm ve Mezopotamya, Ankara: TTK Yayınları, 1987.

Lefebvre, Henri, Karl Marx (Hayatı ve Eserleri), çev: M. Reşat Baraner, I. Baskı, Ankara: Anadolu Yayınları,1968.

Mannan, M. A., İslam Ekonomisi, çev. Bahri Zengin, İstanbul: Fikir Yayınları, 1976.

Marshall G.S. Hodgson, İslamın Serüveni, Bir Dünya Medeniyetinde Bilinç Ve Tarih, İstanbul: İz Yayınc1lik, 1995.

Michel, Thomas, Hristiyan Tanrıbilimine Giriş, İstanbul: Orhan Basımevi, 1991.

Montgomery Watt, Günümüzde İslam ve Hristiyanlık, çev. Turan Koç, İstanbul: İz Yayınları,1991.

Örs, Hayrullah, Musa ve Yahudilik, İstanbul: Remzi Kitabevi, I966.

Sayılı, Aydın, Misırlllarda Ve Mezopotamyalılarda Matematik, Astronomi Ve Tip, Ankara: TTK Basımevi, 1982.

Sedillot, Rene, Değiştokuştan Süpermarkete, Ankara: Dost Kitabevi, 1982.

Somçağ, Selim, Avrupa Feodalizminin Evrimi, İstanbul: Bağlam Yayınları.

Tillich, Paul, Imanın Dinamikleri, Ankara: Ankara Okulu Yayınları, 2000.

Toynbee, Arnold, Tarihçi Açısından Din, çev. İbrahim Canan, İstanbul: Kayıhan Yayınevi, 1978. Toynbee, Arnold, Medeniyet Yargllanıyor, çev. Ufuk Uyan, İstanbul: Yeryüzü Yayınları, 1980. Yüksel, Ahmet Özemre, İslamda Aklın Önemi Ve Sinırı, İstanbul: Denge Yayınları, 1996. Yıldırım, Suat, Mevcut Kaynaklara Göre Hristiyanlık, Ankara: DİB Yayınları, 1988. 